SUPPORTING INFORMATION PARAGRAPH for

\title{
Semisynthesis of dimeric proteins by Expressed Protein Ligation
}

by Barbara Ziaco ${ }^{\mathrm{a}}$, Soccorsa Pensato ${ }^{\mathrm{a}}$, Luca D. D’Andrea ${ }^{\mathrm{b}}$, Ettore Benedetti $^{\mathrm{a}}$, Alessandra Romanelli $^{\mathrm{a} *}$

General experimental

All chemicals and solvents are commercially available (Novabiochem, Sigma-Aldrich, LabScan) and were used without further purification. The pTXB1 vector and the chitin resin were purchased at New England Biolabs; pTrcHisA and Ni-NTA resin were from Invitrogen. Column chromatography was performed on Fluka silica gel 60 (size: $0.04-0.063 \mathrm{~mm}$ ). ${ }^{1} \mathrm{H}$ - and ${ }^{13} \mathrm{C}-\mathrm{NMR}$ spectra were recorded on a Varian Innova instrument $(600 \mathrm{MHz})$ at room temperature. All chemical shifts are expressed in ppm with respect to the signals of the residual protonated solvents $\left(\mathrm{CDCl}_{3}\right.$ or DMSO $\left.\mathrm{d}_{6}\right)$. LCMS analyses of the proteins were run on a Thermo Finnigan instrument equipped with a LCQ Deca XPMax ES source using a Phenomenex Jupiter 5 $\mu$ C4 300Á, 250x2.00 mm column. LCMS analyses of the linker were run on a Thermo Finnigan instrument equipped with a MSQ ES source using a Phenomenex Jupiter $5 \mu \mathrm{C} 18$

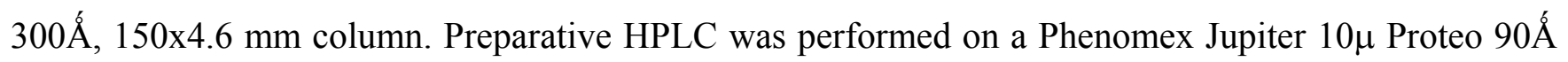
250x10.00 mm column.

\section{Synthesis of the linker $\mathbf{N}-\mathbf{N}^{\prime}$ bis-cysteinyl- ethylendiamine To a solution of ethylendiamine} $(30.1 \mu \mathrm{L}, 0.45 \mathrm{mmol})$ and DIPEA $(485.5 \mu \mathrm{L}, 2.7 \mathrm{mmol})$ in dry DCM $(300 \mu \mathrm{L})$ was added a solution of BocCys(Trt)OH (500mg, $1.08 \mathrm{mmol})$, PyBOP (467 mg, $0.90 \mathrm{mmol}$ ) and HOBT (121.4 mg, $0.90 \mathrm{mmol})$ in dry DCM (2 mL). The reaction was stirred overnight at room temperature. The mixture was extracted with a $5 \% \mathrm{NaHCO}_{3}$ aqueous solution. The organic phase was dried over $\mathrm{MgSO}_{4}$ and the solvent was evaporated under reduced pressure. The residue was purified by silica gel flash chromatography (ethyl 
acetate/petroleum ether, $7 / 3 \mathrm{v} / \mathrm{v}$ ) to afford $427 \mathrm{mg}$ of protected linker N-N' bis[N-tert-butyloxycarbonylS-triphenylmethyl-cysteinyl] ethylendiamine as a yellow oil (99\% Yield).

The Boc/Trt protected linker (159 mg, $0.16 \mathrm{mmol}$ ) was dissolved in $\mathrm{CH}_{2} \mathrm{Cl}_{2} / \mathrm{TFA} / \mathrm{TIS} 50 / 47 / 3 \mathrm{v} / \mathrm{v} / \mathrm{v}(4$ $\mathrm{mL}$ ). Deprotection of the Trt and Boc groups was complete after 5 minutes. The solution was concentrated under reduced pressure and diluted with cold diethyl ether. The precipitated crude product $\mathrm{N}-\mathrm{N}^{\prime}$ bis-cysteinyl- ethylendiamine was dissolved in water, analyzed by LCMS and purified by preparative HPLC with an increasing gradient of $\mathrm{CH}_{3} \mathrm{CN}(0.1 \%$ TFA), in water $(0.1 \% \mathrm{TFA})$ from 1 to $70 \%$ in 30 minutes.

Yield: quantitative

$\mathrm{N}-\mathrm{N}$ ' bis[N-tert-butyloxycarbonyl-S-triphenylmethyl-cysteinyl] ethylendiamine

ESMS: 1: calculated 952.30 u.m.a., found 952.30 ;

${ }^{1} \mathrm{H}$ NMR: $\left(\mathrm{CDCl}_{3}\right)$ 8: 7.45-7.20 (m, 30H Trt); $4.9(\mathrm{~m}, 2 \mathrm{H} \mathrm{C \alpha}) ; 3.1-3-3\left(\mathrm{~m}, 4 \mathrm{H} \mathrm{CH}_{2}-\mathrm{N}\right) ; 2.75(\mathrm{~m}, 2 \mathrm{H}$ $\left.\mathrm{CH}_{2}-\mathrm{S}\right) ; 2.55$ (m, 2H CH $\left.\mathrm{H}_{2} \mathrm{~S}\right) ; 1.6$ (s, 18H Boc). ${ }^{13} \mathrm{C}$ NMR: $\left(\mathrm{CDCl}_{3}\right) \delta 171.7(\mathrm{C}=\mathrm{O}-\mathrm{C} \alpha) ; 144.8(\mathrm{C}=\mathrm{O}$ Boc); 130.0, 128.5, $127.4\left(\mathrm{C}\right.$ Trt); $80.7\left(\mathrm{C}_{\mathrm{q}}\right.$ Boc); $67.6\left(\mathrm{C}_{\mathrm{q}}\right.$ Trt $) ; 54.2(\mathrm{C} \alpha) ; 39.7\left(\underline{\mathrm{CH}}_{2}-\mathrm{N}\right) ; 28.8(\mathrm{Boc}$, $\left.\mathrm{CH}_{2}-\mathrm{S}\right)$.

N-N' bis-cysteinyl- ethylendiamine

ESMS : calculated 267.09, found 265.9

${ }^{1} \mathrm{H}$ NMR (DMSO d $\left.\mathrm{d}_{6}\right) \delta: 8.6 \mathrm{NH} ; 3.9(\mathrm{~m}, 2 \mathrm{H} \mathrm{H \alpha}) ; 3.2\left(\mathrm{~m}, 4 \mathrm{H} \mathrm{CH}_{2}-\mathrm{N}\right) ; 2.9\left(\mathrm{~m}, 2 \mathrm{H} \mathrm{CH}_{2}-\mathrm{S}\right) .{ }^{13} \mathrm{C} \mathrm{NMR}^{2}$ $\left(\mathrm{DMSO} \mathrm{d}_{6}\right) \delta: 170.9(\mathrm{C}=\mathrm{O}) ; 58.1(\mathrm{C} \alpha) ; 42.4\left(\underline{\mathrm{CH}}_{2}-\mathrm{N}\right) ; 29.0\left(\mathrm{CH}_{2}-\mathrm{S}\right)$.

\section{Protein expression and purification}

Escherichia coli BL21 (DE3) cells, transformed with the appropriate plasmid, were grown to mid-log phase at $37^{\circ} \mathrm{C}$ in $\mathrm{LB}$ medium. Protein expression was induced with $0.4 \mathrm{mM}$ isopropyl $\beta$-D- 
thiogalactoside (IPTG) at $37^{\circ} \mathrm{C}$ for $5 \mathrm{~h}$, after which cells were harvested and lysed by sonication. Protein expression was followed by SDS-PAGE (15\%). Protein A-MxeGyrA fusion was purified at room temperature by affinity chromatography on a $\mathrm{Ni}^{2+} \mathrm{NTA}$ resin. Protein was eluted in $50 \mathrm{mM}$ $\mathrm{NaH}_{2} \mathrm{PO}_{4}, 300 \mathrm{mM} \mathrm{NaCl}, 250 \mathrm{mM}$ imidazole $\mathrm{pH} 8$.

Protein B-MxeGyrA- fusion was immobilized and purified on chitin resin, following standard protocol.

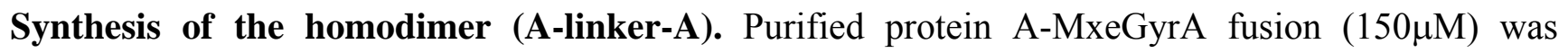
reacted in Phosphate buffer 50mM, 0.2mM MESNA, 0.3mM EDT, pH 7 with 0.5 (or 3) equivalents of linker. Splicing and ligation reactions were performed simultaneously overnight at room temperature. The reaction leads to the homodimer in a 50\% yield. The crude was analysed by LCMS with an increasing gradient of $\mathrm{CH}_{3} \mathrm{CN}(0.1 \%$ TFA), in water $(0.1 \%$ TFA) from 5 to $70 \%$ in 30 minutes. Mass spectrum shows the presence of the homodimer A-linker-A and the protein A (or protein A-linker derivative).

Peptide A sequence: MGGSHHHHHH GMASMTGGQQ MGRDLYDDDD KDRWGSGHIE GR

ES-MS:

Peptide A: calculated 4566.8 Da, found 4567.2 - $1142.6[\mathrm{M}+4 \mathrm{H}]^{4+} ; 1523.0[\mathrm{M}+3 \mathrm{H}]^{3+}$.

A-linker -A: calculated (- Met) 9364.6 Da, found 9363.0- $1873.6[\mathrm{M}+5 \mathrm{H}]^{5+} ; 1561.5[\mathrm{M}+6 \mathrm{H}]^{6+}$.

A-linker calculated 4815.8 Da.; found 4815.6- $[\mathrm{M}+4 \mathrm{H}]^{4+} 1204.9-[\mathrm{M}+3 \mathrm{H}]^{3+} 1606.2$.

Synthesis of the heterodimer (A-linker-B). Purified protein A-MxeGyrA fusion $(50 \mu \mathrm{M})$ was reacted in Phosphate buffer 20mM , 0.18mM MESNA, 0.23mM EDT, pH 7 with a three fold excess of linker. Splicing and ligation reactions were performed simultaneously overnight at room temperature to give the protein A-linker derivative in quantitative yield. The crude was dyalized against deionized water; A- 
linker was purified by preparative HPLC with an increasing gradient of $\mathrm{CH}_{3} \mathrm{CN}(0.1 \% \mathrm{TFA})$, in water ( $0.1 \%$ TFA) from 10 to $45 \%$ in 38 minutes. Protein B-MxeGyrA fusion was immobilized on the chitin resin, splicing was induced incubating the resin in $20 \mathrm{mM}$ Phosphate buffer containing $300 \mathrm{mM} \mathrm{NaCl}$, $50 \mathrm{mM}$ MESNA and $1 \mathrm{mM}$ EDTA, pH7. The thioester was purified by preparative HPLC with an increasing gradient of $\mathrm{CH}_{3} \mathrm{CN}(0.1 \%$ TFA), in water $(0.1 \%$ TFA) from 10 to $40 \%$ in 30 minutes. Analysis by LCMS of the thioester revealed the presence of peptide B lacking the N-terminus Met and a small fraction lacking both N-terminus Met and Ala. These side products are probably generated during the protein work up, due to the presence of proteases. Furthermore coelution of oxidized peptide B $(\mathrm{M}+16)$ with peptide $\mathrm{B}$ was also observed. This product is generated during the splicing reaction, if the solvents were not properly degassed. The purified protein A-linker $(0.36 \mathrm{mM})$ derivative was reacted with one equivalent of thioester protein $\mathrm{B}(0.36 \mathrm{mM})$. Reaction was carried out in $20 \mathrm{mM}$ Phosphate buffer containing $0.18 \mathrm{mM}$ MESNA and $0.23 \mathrm{mM}$ EDT, $\mathrm{pH} 7$ overnight. The crude was analyzed by LCMS with an increasing gradient of $\mathrm{CH}_{3} \mathrm{CN}(0.1 \%$ TFA), in water $(0.1 \%$ TFA) from 5 to $70 \%$ in 30 minutes. Protein A-linker was all converted into the homodimer A-linker-B, while the protein B excess was converted into the EDT-thioester.

Peptide B sequence: MASSRVDGGR EFLEGSS

ESMS:

Peptide B: calculated (-Met) 1653.7, found $1653.7-1653.7[\mathrm{M}+\mathrm{H}]^{+}-[\mathrm{M}+2 \mathrm{H}]^{2+} 827.9$.

Peptide B MESNA thioester: calculated (-Met) 1776.8 , found $1777.4-1777,5[\mathrm{M}+\mathrm{H}]^{+}-[\mathrm{M}+2 \mathrm{H}]^{2+}$ 889.7.

A-linker calculated 4815.8 Da., found 4815.6 - $[\mathrm{M}+4 \mathrm{H}]^{4+} 1204.9-[\mathrm{M}+3 \mathrm{H}]^{3+} 1606.2$.

A-linker-B: calculated 6451.5 Da., found $6450.8-[\mathrm{M}+5 \mathrm{H}]^{5+} 1291.2-[\mathrm{M}+4 \mathrm{H}]^{4+} 1613.7$. 
${ }^{13} \mathrm{C}$ of the linker (2)

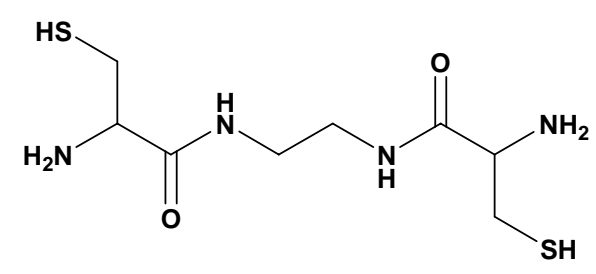

冈 
Expanded region of the ${ }^{13} \mathrm{C}$ of the linker (2)<smiles>NC(CS)C(=O)NCCNC(=O)C(N)CS</smiles>
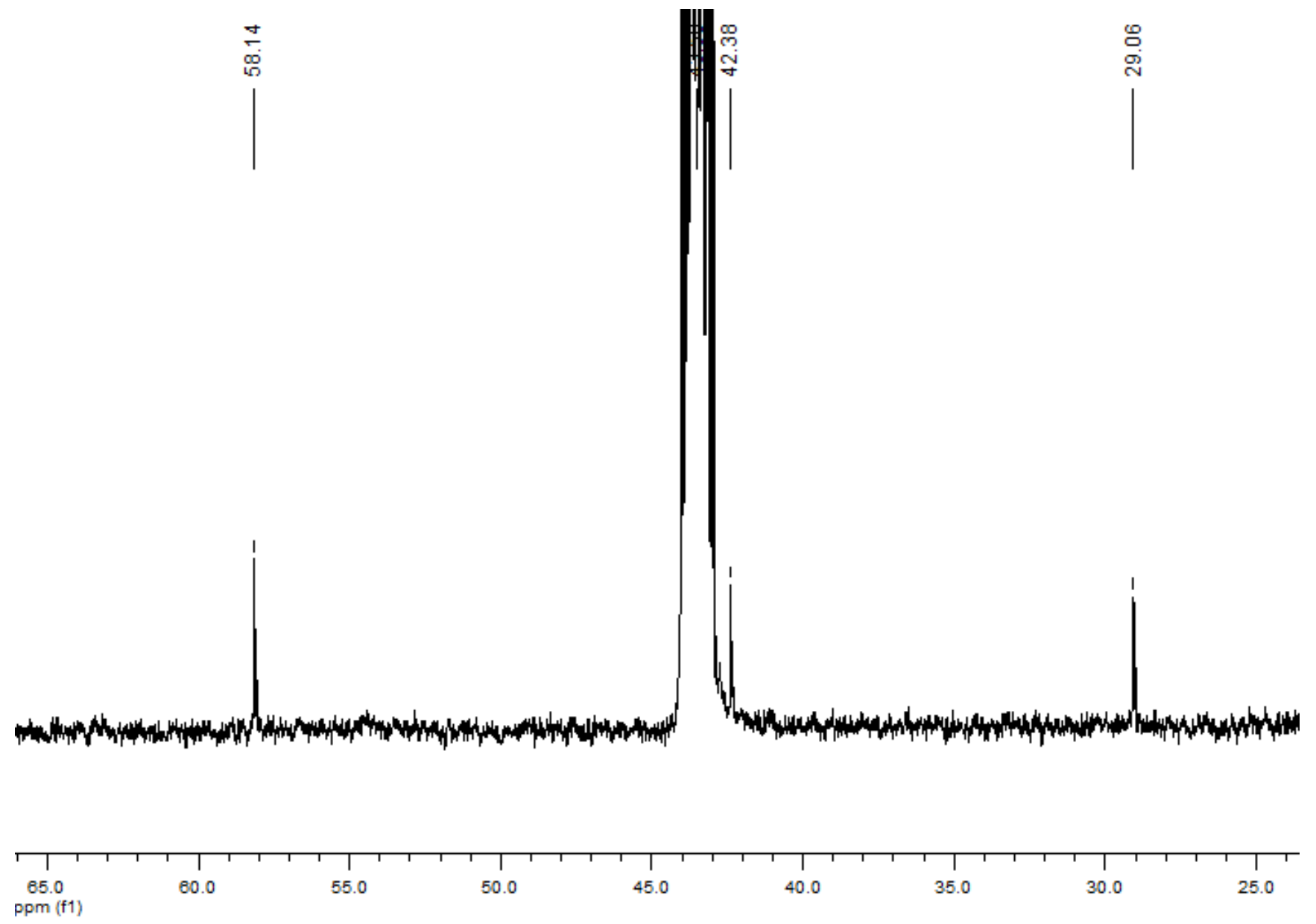
${ }^{1} \mathrm{H}$ NMR of the linker (2)
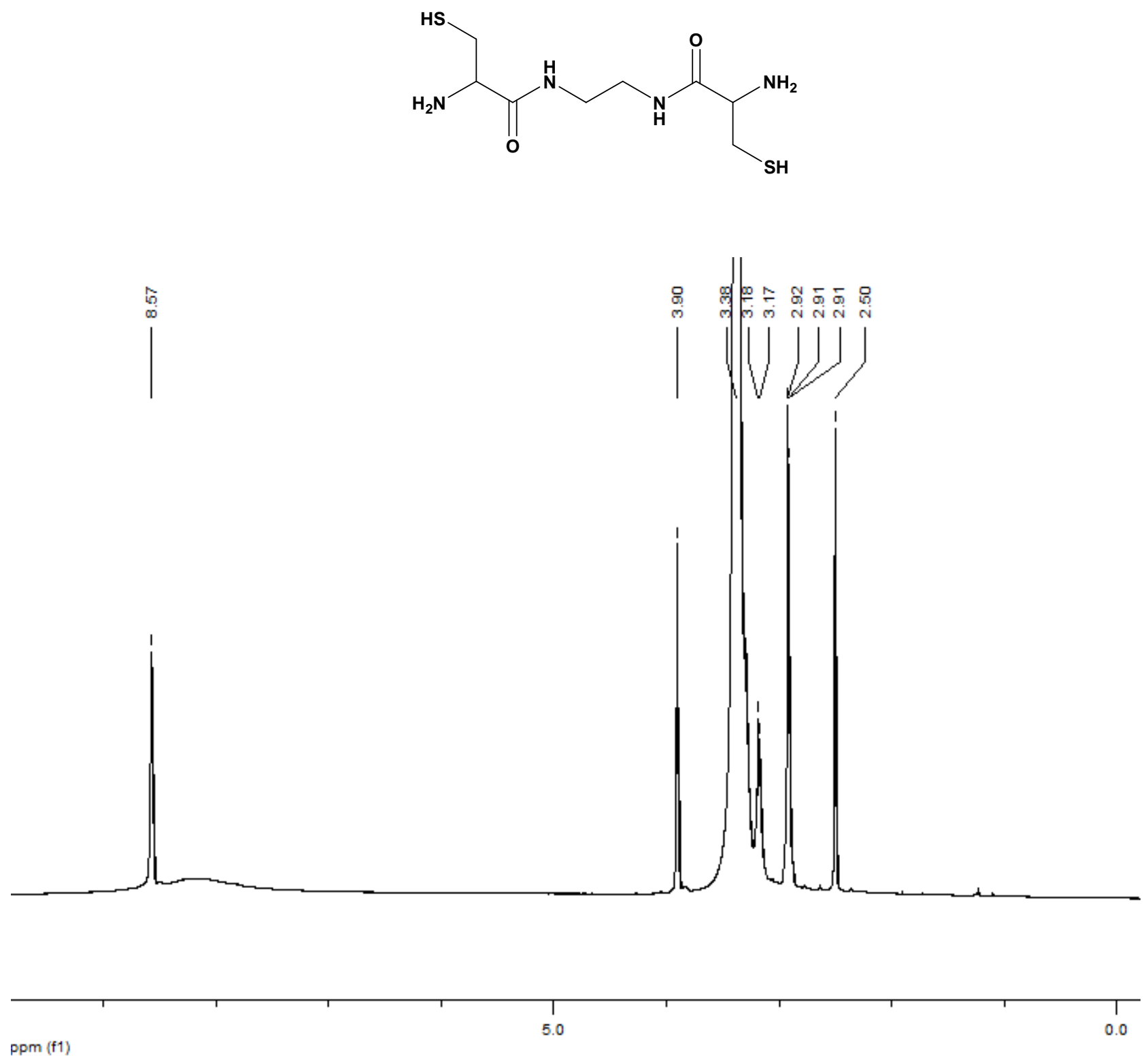
Splicing of the mutated N198A MxeGyrA

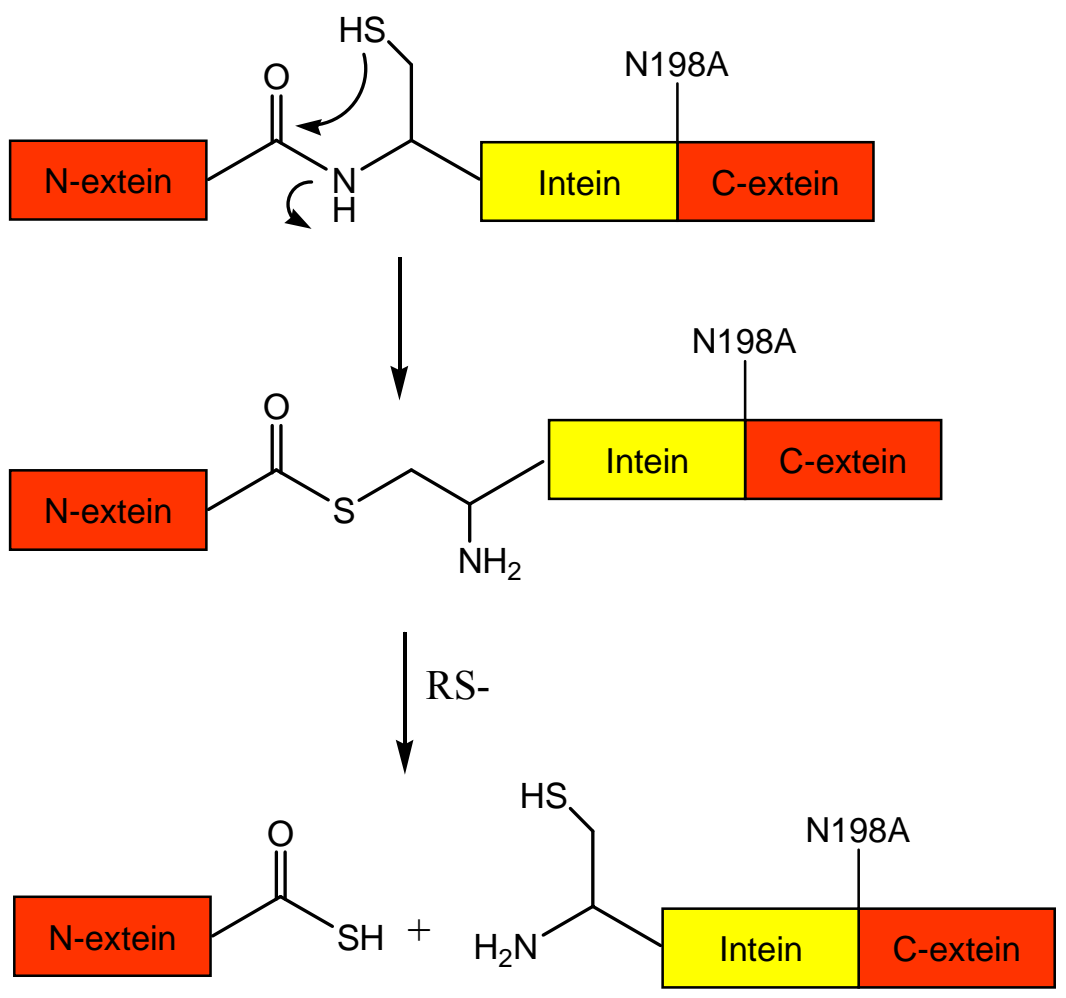


HPLC profiles of non optimized reactions for obtaining the homodimer A-linker-A, with different protein concentrations. ( $\downarrow$ : A-linker; $\uparrow:$ : A-linker-A). HPLC conditions are the same described in the "Synthesis of the homodimer (A-linker-A)" paragraph

1) protein concentration $70 \mu \mathrm{M}$

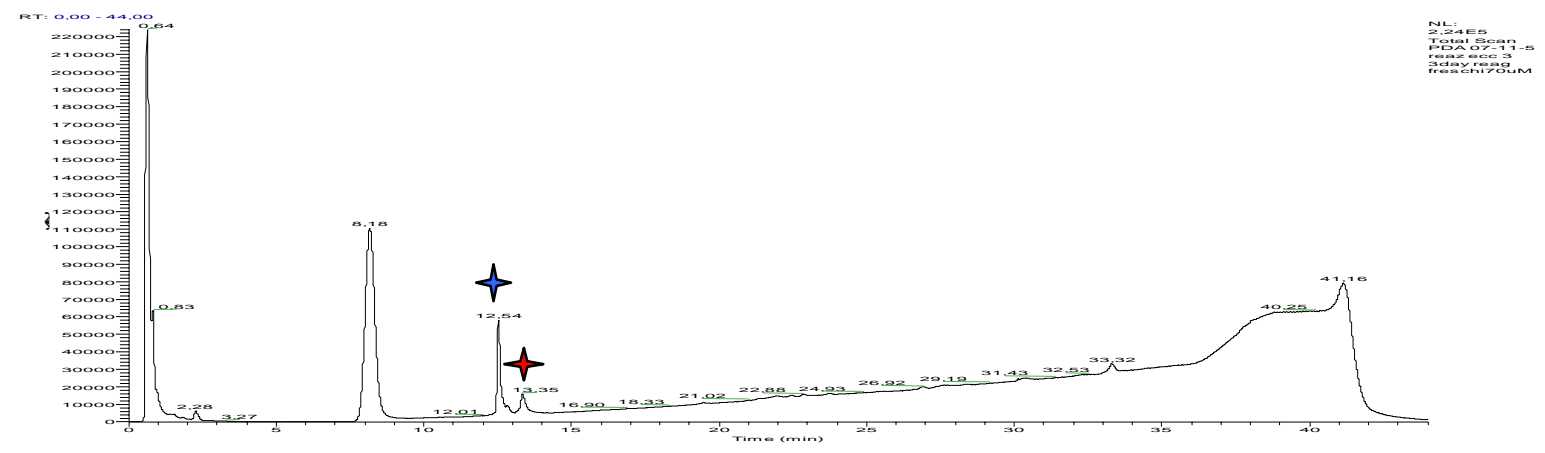

2) protein concentration $110 \mu \mathrm{M}$

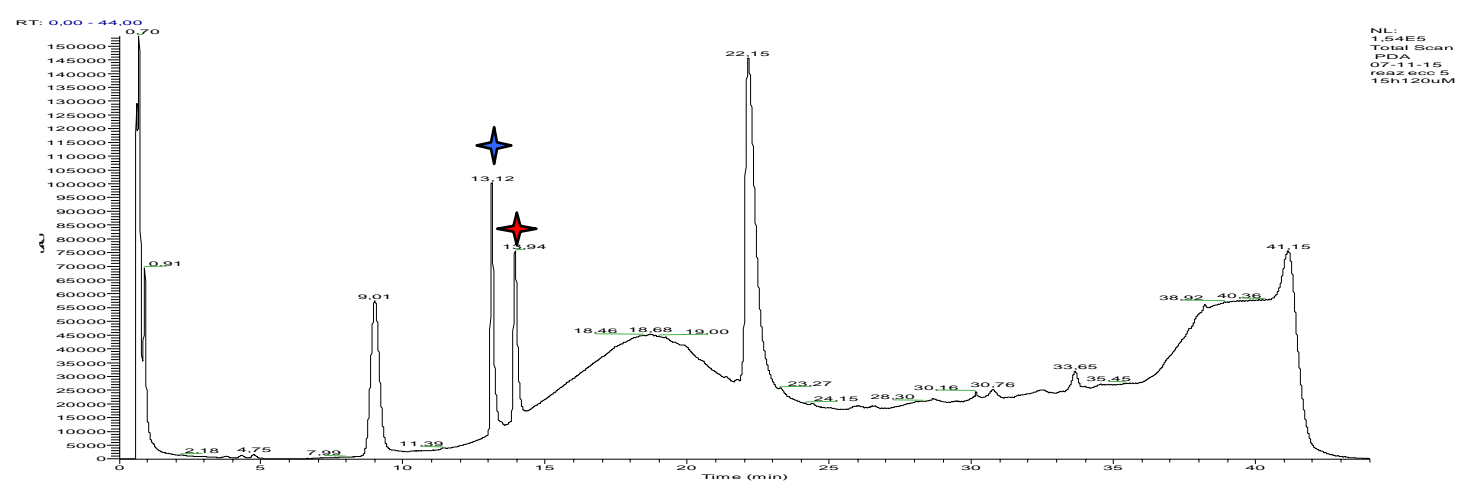

